\title{
Effects of Forage Particle Size and Grain Fermentability in Midlactation Cows. I. Milk Production and Diet Digestibility
}

\author{
K. M. Krause, ${ }^{\star}$ D. K. Combs, ${ }^{*}$ and K. A. Beauchemin† \\ *Department of Dairy Science, \\ University of Wisconsin, Madison 53706 \\ †Research Centre, Agriculture and Agri-Food Canada, \\ Lethbridge, AB, Canada T1J 4B1
}

\begin{abstract}
Our study investigated the effects of, and interactions between, level of dietary ruminally fermentable carbohydrate (RFC) and forage particle size on milk production, nutrient digestibility, and microbial protein yield for dairy cows fed one level of dietary NDF. Eight cows (61 days in milk) were assigned to four treatments in a double $4 \times 4$ Latin square. Treatments were arranged in a $2 \times 2$ factorial design; finely chopped alfalfa silage (FS) and coarse alfalfa silage (CS) were combined with concentrates based on either dry cracked shelled corn (DC; low RFC) or ground highmoisture corn (HMC; high RFC). Diets were fed ad libitum as a total mixed rations with a concentrate to forage ratio of 61:39. Diets based on DC had a predicted $\mathrm{NE}_{\mathrm{L}}$ content of $1.73 \mathrm{Mcal} / \mathrm{kg}$ dry matter (DM), while HMC diets contained $1.80 \mathrm{Mcal} / \mathrm{kg}$ DM. Diets averaged $18.7 \% \mathrm{CP}, 24.0 \% \mathrm{NDF}, 18.3 \% \mathrm{ADF}$, and $27.4 \%$ starch on a DM basis. Mean particle size of the four diets was $6.3,2.8,6.0$, and $3.0 \mathrm{~mm}$ for DCCS, DCFS, HMCCS, and HMCFS, respectively. Increasing level of RFC decreased dry matter intake (DMI) from 25.0 to $23.8 \mathrm{~kg} /$ $\mathrm{d}$ and organic matter intake from 22.3 to $21.1 \mathrm{~kg} / \mathrm{d}$, but intake was not affected by particle size. Milk production averaged 44.0 and $26.8 \mathrm{~kg} / \mathrm{d}$ solids corrected milk (SCM) and was not affected by diet, but increasing level of RFC tended to increase milk yield. Efficiency of milk production, expressed as SCM/DMI, increased from 1.06 to 1.14 when level of RFC was increased. Milk composition or yield of milk components was not affected by diet, and averaged $3.53 \%$ fat, $3.11 \%$ protein, $1.55 \mathrm{~kg} / \mathrm{d}$ fat, and $1.36 \mathrm{~kg} / \mathrm{d}$ protein. Total tract digestibility of DM and OM increased from 71.4 to $73.0 \%$ and 72.4 to $76.1 \%$ for $\mathrm{DM}$ and $\mathrm{OM}$, respectively, when level of RFC was increased. Total tract digestibility of fiber was unaffected by diet, but total tract
\end{abstract}

Received September 12, 2001.

Accepted February 4, 2002.

Corresponding author: D. K. Combs; e-mail: dkcombs@facstaff. wisc.edu. starch digestibility increased from 93.1 to $97.4 \%$ when HMC replaced DC. Total urinary excretion of the purine derivatives uric acid and allantoin increased from 415 to $472 \mathrm{mmol} / \mathrm{d}$ when level of RFC was increased, and calculated microbial $\mathrm{N}$ supply increased from 315 to $365 \mathrm{~g} / \mathrm{d}$. When expressed as per kilogram of digestible OMI, increasing level of RFC tended to increase microbial N supply ( $20.4 \mathrm{vs} .22 .2 \mathrm{~g} / \mathrm{kg}$ ). Cow productivity was not affected by forage particle size and ruminally fermentable carbohydrates in this study.

(Key words: particle size, ruminally fermentable carbohydrate, production, digestibility)

Abbreviation key: $\mathbf{C S}=$ coarse silage, $\mathbf{D C}=$ dry corn, DOMI = digestible organic matter intake, eNDF = effective NDF, ERD = effective rumen degradability, FS = fine silage, HMC = high moisture corn, $\mathbf{R F C}=$ ruminally fermentable carbohydrate.

\section{INTRODUCTION}

Energy and fiber requirements of dairy cows in early lactation are not easily met because their energy expenditure exceeds the energy consumed. Diets high in starch and low in fiber are fed to increase intake of energy, but these diets increase the risk of ruminal acidosis.

Milk fat percentage response (Armentano and Pereira, 1997), time spent chewing (Sudweeks et al., 1981), and ruminal $\mathrm{pH}$ (Mertens, 1997) have been used to determine the effectiveness of fiber in diets for dairy cows. The effectiveness of NDF is related to the total ability of a feed to replace forage in a ration so that the percentage of fat in milk produced by cows eating the ration is effectively maintained (Mertens, 1997). Diets low in effective fiber and high in fermentable carbohydrates can affect ruminal fermentation negatively. In vitro studies have shown that fiber digestion is greatly depressed when $\mathrm{pH}$ declines below 6.0 , and that the optimal ruminal $\mathrm{pH}$ for fiber digestion is around 6.5 (Shriver et al., 1986). However, ruminal $\mathrm{pH}$ of growing cattle and high producing dairy cows is often below 6.0 despite diets balanced to include a 
minimum amount of forage to ensure rumen function. A decrease in fiber digestion because of low ruminal $\mathrm{pH}$ can decrease ruminal digestion of the diet (Shriver et al., 1986) and, therefore, negatively affect production.

The Cornell Net Carbohydrate and Protein System indicates that diets containing less than 20\% NDF from forage reduce microbial yield (Russell et al., 1992). Strobel and Russell (1986) reported that mixed ruminal bacteria incubated in vitro with a mixed carbohydrate substrate produced $13.6 \mathrm{mg} \mathrm{DM} / \mathrm{mmol} \mathrm{ATP}$ produced at $\mathrm{pH} 5.7$ versus $21.2 \mathrm{mg} \mathrm{DM} / \mathrm{mmol}$ ATP produced at $\mathrm{pH}$ 6.7. Depression in carbohydrate utilization at low $\mathrm{pH}$ is a primary factor contributing to the lower protein yield, but this does not completely explain the decrease in protein yield. Because certain amino acids are often limiting postruminally (NRC, 2001), depressions in microbial protein synthesis could have a negative effect on animal productivity. However, information is lacking concerning the in vivo effects of diets low in effective fiber and high in fermentable carbohydrates on the protein yield of rumen microbes.

The objectives of this study were to investigate the effects of, and interactions between, level of ruminally fermentable carbohydrate in the diet and forage particle size on milk production, digestibility, and microbial yield at constant level of dietary NDF.

\section{MATERIALS AND METHODS}

\section{Cows and Diets}

Eight multiparous Holstein cows were assigned randomly to one of two squares in a double $4 \times 4$ Latin square. Cows were fitted with ruminal cannulas and averaged $61 \pm 8$ DIM at the start of the experiment. Average BW was $580 \pm 49 \mathrm{~kg}$ at the beginning of the experiment and $617 \pm 53 \mathrm{~kg}$ at the end of the experiment. Experimental periods were $28 \mathrm{~d}$ in duration ( 16 $\mathrm{d}$ of treatment adaptation and $12 \mathrm{~d}$ of data collection). Treatments were arranged in a $2 \times 2$ factorial design; two levels of forage particle size (fine and coarse) were combined with concentrates based on either dry cracked shelled corn (DC; $89.9 \%$ DM) or ground highmoisture shelled corn (HMC; $74.2 \%$ DM). The highmoisture shelled corn was treated with propionic acid (6.7 kg/tonne) during ensiling. Dry cracked shelled corn and ground high-moisture shelled corn were used in this trial because of their differences in ruminal starch degradability. One report from the literature indicated that 65 and $86 \%$ of the starch in dry cracked shelled corn and in high-moisture corn is degraded in the rumen, respectively (Nocek and Tamminga, 1991). Dry cracked corn was also used because its mean parti- cle size was very similar to the particle size of the high-moisture corn, whereas the dry ground corn available for this trial was ground finer than the highmoisture corn. First-cut, wilted alfalfa silage that was harvested at the early bloom stage of maturity was the sole source of forage. The forage was chopped with a Gehl Implement, model number 865 forage chopper (Gehl Implement, West Bend, WI), with a head model number 1210 adjusted to cut forage at $1.9-\mathrm{cm}$ theoretical length of cut. Forage was ensiled in a $3.7 \times 12.2 \mathrm{~m}$ concrete stave silo. This silage provided the coarse silage (CS) for the diets. Finely chopped silage (FS) was obtained by recutting the ensiled alfalfa silage through a $1.9-\mathrm{cm}$ screen in a forage recutter (Gehl) daily for the duration of the trial. Geometric particle size of the forages and the corn grain is given in Table 1. All diets were formulated to meet or exceed the requirements of a $600-\mathrm{kg}$ multiparous cow producing $45 \mathrm{~kg}$ of milk/d using CPM-Dairy (1997). Diet formulations are given in Table 2.

Diets were fed as a TMR with a ratio of concentrate to forage of 61:39 (DM basis). Cows were fed ad libitum (10\% refusals), and feed was offered twice daily at 0700 and $1900 \mathrm{~h}$ in equal portions. Intake and milk production were recorded daily throughout the experiment. Feed and ort samples were taken twice weekly, and intakes of nutrients were corrected for nutrient contents of orts. Dry matter $\left(60^{\circ} \mathrm{C}\right)$ of feed components was determined weekly, and diets were adjusted to account for changes in DM content.

Cows were cared for according to guidelines of The Research Animal and Resource Committee of the Univ. of Wisconsin-Madison, and all experimental procedures performed on the animals were approved. Cows were housed in stalls bedded with rubber mattresses and wood shavings and were milked twice daily at 0300 and $1500 \mathrm{~h}$ in a milking parlor. Cows were turned outside for 1 to $2 \mathrm{~h}$ daily after being milked, except on days when total urine output was recorded. Milk was sampled on consecutive p.m. and a.m. milkings on 2 $\mathrm{d}$ during each period, and milk components were determined by AgSource, Menomonie, Wisconsin, using a near-infrared reflectance spectroscopy analyzer (MilkoScan 605; Foss Electric, Hillerød, Denmark).

\section{Feed Analysis}

Composite samples of all feeds, diets, and orts were obtained during each experimental period. Dried samples were ground to pass a 1-mm screen (Wiley Mill, Arthur H. Thomas, Philadelphia, PA). Analytical DM content of feeds was determined by oven-drying at $135^{\circ} \mathrm{C}$ for $2 \mathrm{~h}$; OM was determined by ashing at $500^{\circ} \mathrm{C}$ for $16 \mathrm{~h}$, and $\mathrm{CP}$ was determined by the micro-Kjeldahl 
Table 1. Mean geometric particle size of corn grain, forage, and TMR.

\begin{tabular}{lcl}
\hline & Mean $(\mathrm{mm})$ & SD $(\mathrm{mm})$ \\
\hline Dry cracked shelled corn $^{1}$ & 1.55 & 0.06 \\
High-moisture shelled corn $_{\text {Coarse alfalfa silage }^{2}}$ & 1.60 & 0.13 \\
Fine alfalfa silage $_{\text {HMCFS }^{3}}$ & 13.6 & 1.6 \\
HMCCS $_{\text {DCFS }}$ & 3.7 & 0.4 \\
DCCS & 3.0 & 0.2 \\
\hline
\end{tabular}

${ }^{1}$ Mean geometric particle size of corn grain was determined by dry-sieving according to ASAE (1995) standards.

${ }^{2}$ Mean geometric particle sizes of forages and TMR were determined by dry-sieving using the UW forage particle size separator in accordance with ASAE standard S424 (1988). Diagonal diameters of openings in screens were: $26.90,18.00,8.98,5.61$, and $1.65 \mathrm{~mm}$. Distribution of particles, in percent of total mass, on the five screens and the pan, respectively, were: Coarse alfalfa silage: $20.3,21.4,34.5,8.9,10.7,4.2$; fine alfalfa silage: $0.3,0.2,18.1,19.1,44.8,17.5$; HMCFS: 0.0, 0.1, 15.1, 18.5, 35.3, 31.1; HMCCS: 6.7, 15.6, 24.2, 14.8, 16.6, 21.9; DCFS: 0.0, 0.0, 11.0, 19.4, 39.1, 30.5; DCCS: 8.3, 16.2, 20.9, 15.2, 20.0, 19.4 .

${ }^{3}$ Treatments: HMCFS $=$ High-moisture corn and fine silage, HMCCS $=$ high-moisture corn and coarse silage, DCFS = dry corn and fine silage, DCCS = dry corn and coarse silage.

method (AOAC, 1990). The NDF fraction was determined using $\alpha$-amylase (Sigma no. A3306: Sigma Chemical Co., St. Louis, MO) and sodium sulfite (Van
Soest et al., 1991) and was not corrected for ash content; ADF was determined using the procedure described by Goering and Van Soest (1970). Starch was

Table 2. Composition and nutrient content of dietary treatments.

\begin{tabular}{|c|c|c|c|c|}
\hline & \multicolumn{4}{|c|}{ Treatments $^{1}$} \\
\hline & HMCFS & HMCCS & DCFS & DCCS \\
\hline \multicolumn{5}{|l|}{ Feed stuff, \% of DM } \\
\hline Alfalfa silage ${ }^{2}$, fine & 39.3 & & 39.3 & \\
\hline Alfalfa silage ${ }^{2}$, coarse & & 39.3 & $\ldots$ & 39.3 \\
\hline High-moisture shelled corn & 36.6 & 36.6 & . & \\
\hline Dry cracked shelled corn & $\ldots$ & $\ldots$ & 36.6 & 36.6 \\
\hline Wheat middlings & 9.4 & 9.4 & 9.4 & 9.4 \\
\hline Corn gluten meal & 3.1 & 3.1 & 3.1 & 3.1 \\
\hline Soybean, whole roasted & 7.9 & 7.9 & 7.9 & 7.9 \\
\hline Soybean meal, $44 \%$ & 2.0 & 2.0 & 2.0 & 2.0 \\
\hline Blood meal & 0.6 & 0.6 & 0.6 & 0.6 \\
\hline Smartamine $^{\mathrm{TM}} \mathrm{ML}^{3}$ & 0.2 & 0.2 & 0.2 & 0.2 \\
\hline Dicalcium phosphate & 0.2 & 0.2 & 0.2 & 0.2 \\
\hline Calcium carbonate & 0.2 & 0.2 & 0.2 & 0.2 \\
\hline $\mathrm{ADE}$ vitamin $\operatorname{mix}^{4}$ & 0.1 & 0.1 & 0.1 & 0.1 \\
\hline Salt and trace mineral $\operatorname{mix}^{5}$ & 0.4 & 0.4 & 0.4 & 0.4 \\
\hline $\mathrm{NE}_{\mathrm{L}}^{6}, \mathrm{Mcal} / \mathrm{kg} \mathrm{DM}$ & 1.80 & 1.80 & 1.73 & 1.73 \\
\hline $\mathrm{DM}, \%$ & 58.7 & 58.6 & 63.3 & 60.0 \\
\hline $\mathrm{OM}, \%$ of $\mathrm{DM}$ & 93.7 & 93.6 & 93.8 & 93.7 \\
\hline $\mathrm{CP}, \%$ of $\mathrm{DM}$ & 18.6 & 18.5 & 18.8 & 18.8 \\
\hline $\mathrm{NDF}, \%$ of $\mathrm{DM}$ & 24.8 & 23.2 & 23.4 & 24.6 \\
\hline $\mathrm{eNDF}^{7}, \%$ of DM & 14.4 & 13.6 & 14.4 & 13.6 \\
\hline $\mathrm{ADF}, \%$ of $\mathrm{DM}$ & 19.0 & 17.7 & 17.8 & 18.8 \\
\hline Starch, \% of DM & 28.2 & 29.0 & 26.9 & 25.2 \\
\hline
\end{tabular}

${ }^{1}$ Treatments: HMCFS = High-moisture corn and fine silage, HMCCS $=$ high-moisture corn and coarse silage, DCFS = dry corn and fine silage, DCCS = dry corn and coarse silage.

${ }^{2}$ Alfalfa silage contained $41.9 \% \mathrm{DM}, 19.3 \% \mathrm{CP}, 36.7 \% \mathrm{NDF}$, and $29.9 \% \mathrm{ADF}$ on a DM basis.

${ }^{3}$ Rhône-Poulenc Animal Nutrition, 500 Northridge Road, Atlanta, GA 30350, USA.

${ }^{4} 3308 \mathrm{IU}$ of vitamin $\mathrm{A} / \mathrm{g}, 1103 \mathrm{IU}$ of vitamin $\mathrm{D} / \mathrm{g}$, and $11.03 \mathrm{IU}$ of vitamin $\mathrm{E} / \mathrm{g}$.

${ }^{5} 0.55 \% \mathrm{Mn}, 0.55 \% \mathrm{Zn}, 0.35 \% \mathrm{Fe}, 0.14 \% \mathrm{Cu}, 0.008 \% \mathrm{I}, 0.006 \%$ Se, and $0.002 \%$ Co.

${ }^{6}$ Based on tabular values.

${ }^{7}$ Estimated using the eNDF values of 0.87 for coarse silage and 0.75 for finely chopped silage as suggested by Mertens (1997). 
determined by a colorimetric assay including a pure cornstarch sample as described by Bal et al. (2000).

Particle size of forages and TMR was determined by dry-sieving using an oscillating screen particle size separator according to ASAE standard S424 (Am. Natl. Standards Inst., 1988). Particle size of the corn grain was determined by dry-sieving according to ASAE (1995) standards.

\section{Digestibility}

Lanthanum in solution $(0.2 \mathrm{~g} / \mathrm{ml})$ was used as a marker to measure total tract digestibility (Hartnell and Satter, 1979) and was ruminally dosed at $12-\mathrm{h}$ intervals for the last $14 \mathrm{~d}$ of each period to provide 0.8 $\mathrm{g}$ of La per cow per day. Fecal samples were collected at different times of the day during a 5-d interval concurrent with fecal sampling for rate of passage measurements. Sampling times differed such that the entire 24-h day was represented to account for possible diurnal variation. Fecal samples were dried, ground to pass a 1-mm screen, pooled by period for each cow and dry-ashed at $500^{\circ} \mathrm{C}$ for $16 \mathrm{~h}$. Concentrations of La were determined by direct current plasma emission spectroscopy (Spectra Metrics, Inc., subsidary of Beckman Instruments, Inc., Andover, MA; Combs and Satter, 1992). Total tract nutrient digestibilities were calculated from fecal La concentration and nutrient concentrations in diets fed orts and feces.

\section{In Sacco Measurements}

Ruminal degradation of TMR was measured using large $(25-\times 35-\mathrm{cm})$, in situ bags made of Dacron polyester cloth with a pore size of $52 \pm 5 \mu$. Approximately 80 $\mathrm{g}$ (as fed) of whole TMR samples were weighed into bags, soaked in warm water for $10 \mathrm{~min}$, and placed in large mesh retaining sacs before being incubated ruminally for $0,3,4,5,6,12,24,48$, and $96 \mathrm{~h}$. Only one bag per time point was incubated for $3,4,5$, and 6 $\mathrm{h}$, whereas other time points were done in duplicate. After removal from the rumen, bags were washed under cold, running tap water, and then machine-washed twice in cold water using a rinse cycle with 2 min of agitation. The $0 \mathrm{~h}$ time point bags were not placed in the rumen, but were subject to the same washing procedure. Bags were dried at $60^{\circ} \mathrm{C}$ for $72 \mathrm{~h}$.

The kinetics of DM disappearance in sacco were estimated using nonlinear least squares (PROC NLIN of SAS; SAS, 1998). For each cow and period, the following model (McDonald, 1981) was fitted to the percentage of DM disappearance:

$$
y=a+b\left(1-e^{-k_{d}(t-L)}\right) \text { for } t>L,
$$

where $\mathrm{a}=$ soluble fraction $(\%) ; \mathrm{b}=$ slowly digestible fraction $(\%) ; \mathrm{k}_{\mathrm{d}}=$ fractional rate of disappearance $\left(\% \mathrm{~h}^{-1}\right) ; \mathrm{L}=$ lag time $(\mathrm{h})$; and $\mathrm{t}=$ incubation time $(\mathrm{h})$. The indigestible fraction, referred to as ' $c$ ' in the results, was calculated by difference.

\section{Rate of Passage}

Lithium-Co-EDTA and Cr-mordanted fiber were prepared as described by Udén et al. (1980) and used as markers for liquid and solid passage rates, respectively. The Li-Co-EDTA was dried and ground using a mortar and pestle; Cr-mordanted fiber was prepared by mordanting wheat straw NDF ground through a $6-\mathrm{mm}$ screen using a Wiley mill. Markers were placed in the rumen at the time of the morning feeding, and no attempt was made to manually mix markers with rumen contents. Fecal grab samples were taken at $0,6,10$, $14,18,22,26,30,36,42,48,54,60,72,84,96$, and 120 $\mathrm{h}$ after dosing to determine the rate of passage. Samples were dry-ashed, and fecal marker concentrations of $\mathrm{Cr}$ and Co were determined by direct current plasma emission spectroscopy (Spectra Metrics, Inc., subsidiary of Beckman Instruments, Inc., Andover, MA; Combs and Satter, 1992).

Fecal $\mathrm{Cr}$ and Co excretion curves were fitted to the double-compartment model represented by two exponential constants and a time delay (Grovum and Williams, 1973):

$$
\begin{gathered}
\mathrm{Y}=\mathrm{Ae}^{-\mathrm{k} 1(\mathrm{t}-\mathrm{TT})}-\mathrm{Ae}^{-\mathrm{k} 2(\mathrm{t}-\mathrm{TT})}, \mathrm{k} 1<\mathrm{k} 2 \text { for } \mathrm{t} \geq \mathrm{TT} \\
\mathrm{Y}=0 \text { for } \mathrm{t}<\mathrm{TT},
\end{gathered}
$$

where $\mathrm{Y}=$ marker concentration $(\mathrm{ppm}) ; \mathrm{A}=$ scale parameter; $\mathrm{k} 1=$ ruminal rate of passage $(\% / \mathrm{h}) ; \mathrm{k} 2=$ lower digestive tract rate of passage $(\% / \mathrm{h}) ; \mathrm{t}=$ sampling time post dosing (h); and TT = transit time. Total mean retention time in the digestive tract was calculated as the sum of retention in the rumen $(1 / \mathrm{k} 1)$ and in the lower digestive tract $(1 / \mathrm{k} 2)$ plus the transit time (TT). Data were analyzed by nonlinear regression using the NLIN (iterative Marquardt method) procedure of SAS (SAS, 1998).

\section{Microbial Protein Synthesis}

Microbial protein synthesis was not measured directly. Instead, the urinary excretion of the purine derivatives allantoin and uric acid were used as an estimate of microbial $\mathrm{N}$ flow to the duodenum. On three consecutive days in each experimental period, total urine was collected using indwelling catheters (24"-, 75-cc balloon lubricious catheter, C. R. Bard, Inc., Covington, CA). Containers with $500 \mathrm{ml}$ of $1.5 \mathrm{~N} \mathrm{H}_{2} \mathrm{SO}_{4}$ 
were attached to each cow, and output of urine was measured twice daily. After recording the volume of urine excreted, acidified urine was mixed, and $20-\mathrm{ml}$ samples were taken, diluted to $100 \mathrm{ml}$ with tap water and frozen $\left(-20^{\circ} \mathrm{C}\right)$ for later analysis. Concentration of allantoin in urine was determined colorimetrically using the method described by Chen and Gomes (1992) however, $1 \mathrm{M} \mathrm{HCl}$ was used instead of $0.5 \mathrm{M} \mathrm{HCl}$ in the assay in order to keep $\mathrm{pH}<3$. Samples were diluted 10 times with tap water in the laboratory to a final dilution of 50 before analysis. Uric acid in urine was determined colorimetrically using a diagnostic uric acid reagent (procedure no. 685, Sigma Diagnostics). For the uric acid assay, $1 \mathrm{ml}$ of reagent was used with $50 \mu \mathrm{l}$ of urine diluted 25 times (samples were diluted five times with tap water in the lab before analysis). Purine absorption and intestinal flow of microbial $\mathrm{N}$ was calculated using the assumptions and equations given by Chen and Gomes (1992). The quantitative relationship between absorption of microbial purines (X mmol/d), and excretion of purine derivatives in urine can be described by the following equation:

$$
\mathrm{Y}=0.85 \mathrm{X}+\left(0.0385 \mathrm{~W}^{0.75}\right),
$$

where $\mathrm{W}^{0.75}$ represents the metabolic $\mathrm{BW}(\mathrm{kg})$ of the animal. The slope of 0.85 represents the recovery of absorbed purines as purine derivatives in urine. The component within parenthesis represents the net endogenous contribution of purine derivatives to total excretion after correction for the utilization of microbial purines by the animal. The following factors were used to calculate intestinal flow of microbial $\mathrm{N}(\mathrm{g} \mathrm{N} / \mathrm{d}$ ) from the microbial purines absorbed (X mmol/d): Digestibility of microbial purines was assumed to be 0.83 ; the $\mathrm{N}$ content of purines was $70 \mathrm{mg} \mathrm{N} / \mathrm{mmol}$; and the ratio of purine- $\mathrm{N}$ to total $\mathrm{N}$ in mixed rumen microbes was taken as 11.6:100. Thus, microbial $\mathrm{N}$ was calculated as:

$$
\begin{gathered}
\text { Microbial N supply }(\mathrm{g} / \mathrm{d})=(\mathrm{X} \times 70) / \\
(0.83 \times 0.116 \times 1000)=0.727 \times \mathrm{X}
\end{gathered}
$$

This assumes that the purine to protein ratio in mixed rumen microbes was unchanged by dietary treatment.

\section{Statistical Analysis}

Data on all variables were analyzed using the mixed model procedure in SAS (SAS, 1998); period, level of RFC, particle size of forage, and the interaction of RFC and forage were fixed effects in the model, and period was used as a repeated measurement with first-order auto regressive covariance structure. The random statement included square and cow within square. The model used for intake and production variables, digestibilities and purine derivative excretion data is shown below.

$$
\begin{aligned}
\mathrm{Y}_{\mathrm{ijklm}}= & \mu+\mathrm{S}_{\mathrm{i}}+\mathrm{C}_{\mathrm{j}(\mathrm{i})}+\mathrm{P}_{\mathrm{k}}+\mathrm{M}_{\mathrm{l}}+\mathrm{F}_{\mathrm{m}} \\
& +(\mathrm{M} \times \mathrm{F})_{\mathrm{lm}}+\mathrm{e}_{\mathrm{ijklm}},
\end{aligned}
$$

where $\mu$ = overall mean; $\mathrm{S}_{\mathrm{i}}=$ random effect of square (i $=1$ to 2$) ; \mathrm{C}_{\mathrm{j}(\mathrm{i})}=$ random effect of cow within square $(\mathrm{j}=$ 1 to 4); $\mathrm{P}_{\mathrm{k}}=$ fixed effect of period analyzed as repeated measurements ( $\mathrm{k}=1$ to 4$) ; \mathrm{M}_{1}=$ fixed effect of level of RFC ( $1=1$ to 2$) ; F_{m}=$ fixed effect of forage particle size $(\mathrm{m}=1$ to 2$) ;(\mathrm{M} \times \mathrm{F})_{\mathrm{lm}}=$ fixed effect of interaction of $\mathrm{M}_{\mathrm{l}}$ and $\mathrm{F}_{\mathrm{m}}$; and $\mathrm{e}_{\mathrm{ijklm}}=$ random residual error, assumed to be normally distributed. Significance was declared at $P \leq 0.05$. A trend was considered to exist if $0.05<P \leq$ 0.10 . All reported values are least square means unless otherwise stated.

\section{RESULTS AND DISCUSSION}

\section{Feed Particle Size and Intakes}

Analysis of particle size of forage indicated that the alfalfa silage was coarsely chopped (Table 1). The geometric mean particle size of $13.6 \mathrm{~mm}$ was considered to be above the threshold of $6.4 \mathrm{~mm}$ that is reported to reduce rumination time and cause milk fat depression when dairy cows are fed chopped alfalfa hay as forage (Woodford et al., 1986). The mean geometric particle size of the finely chopped silage was below this threshold. All diets used in this study were relatively low in NDF (Table 2). Based on the low NDF content of the diets and the small particle size of the finely chopped forage, the diets based on finely chopped silage were predicted to be inadequate in level of effective NDF.

Based on the diagonal diameter of the screens in the UW forage particle size separator (ASAE standard S424, American National Standards Institute, 1988), the two top screens of the UW forage particle size separator represent the top screen of the Penn State particle size separator, whereas screen number three represents the middle screen of the Penn State particle size separator and the last two screens the pan. Using this approximation, the forages and TMR had the following distribution on the top screen, middle screen, and pan of the Penn State particle size separator ( $\%$ as fed): CS: 41, 35, 24; FS: 0, 18, 82; HMCFS: 0, 15, 85; HMCCS: 22, 24, 54; DCFS: 0, 11, 89; DCCS: 24, 22, 55.

Intakes of DM, OM, and nutrients are shown in Table 3. Intakes of DM and OM were higher for DC than for HMC diets. Other studies have found no difference in DMI when comparing dry corn versus high-moisture corn fed to dairy cows (Knowlton et al., 1998; Ying et 
Table 3. Effects of level of ruminally fermentable carbohydrates and forage particle size on intake.

\begin{tabular}{|c|c|c|c|c|c|c|c|c|}
\hline \multirow[b]{2}{*}{ Intake, $\mathrm{kg} / \mathrm{d}$} & \multicolumn{4}{|c|}{ Treatments $^{1}$} & \multirow[b]{2}{*}{$\mathrm{SED}^{2}$} & \multicolumn{3}{|c|}{ Statistical significance ( $P$-value $)$} \\
\hline & HMCFS & HMCCS & DCFS & DCCS & & $\mathrm{RFC}^{3}$ & Forage & $\begin{array}{l}\text { RFC } \times \\
\text { Forage }\end{array}$ \\
\hline $\mathrm{DM}$ & 23.4 & 24.1 & 24.7 & 25.3 & 0.7 & 0.01 & 0.12 & 0.89 \\
\hline $\mathrm{OM}$ & 20.8 & 21.3 & 22.0 & 22.6 & 0.6 & 0.0095 & 0.19 & 0.98 \\
\hline $\mathrm{NDF}$ & 5.59 & 5.18 & 5.38 & 5.82 & 0.28 & 0.30 & 0.92 & 0.05 \\
\hline $\mathrm{eNDF}^{4}$ & 3.17 & 3.11 & 3.05 & 3.49 & 0.16 & 0.27 & 0.11 & 0.05 \\
\hline $\mathrm{ADF}$ & 4.22 & 3.91 & 4.08 & 4.41 & 0.20 & 0.24 & 0.94 & 0.04 \\
\hline Starch & 6.39 & 6.91 & 6.80 & 6.18 & 0.34 & 0.51 & 0.85 & 0.03 \\
\hline
\end{tabular}

\footnotetext{
${ }^{1}$ Treatments: HMCFS = High-moisture corn and fine silage, HMCCS $=$ high-moisture corn and coarse silage, DCFS $=$ Dry corn and fine silage, DCCS $=$ dry corn and coarse silage.

${ }^{2} \mathrm{SED}=$ Standard error of difference.

${ }^{3} \mathrm{RFC}=$ Ruminally fermentable carbohydrate.

${ }^{4}$ Estimated by multiplying NDF intake with percent eNDF of total NDF.
}

al., 1998). However, the effect of corn moisture on DMI seems to depend on level of corn in the diet (Oba and Allen, 2000a). Intake of DM decreased when high-moisture corn replaced dry corn in diets containing $31 \%$ starch but not in diets containing $21 \%$ starch (Oba and Allen, 2000a). Diets fed in the current study were intermediate in starch content; $28.6 \%$ for HMC diets and $26.1 \%$ for DC diets.

Forage particle size did not affect DMI in the current study. This is consistent with other studies feeding diets above $40 \%$ concentrate (Shaver et al., 1986; Woodford et al., 1986). However, in a study by Woodford and Murphy (1988), reducing forage particle size by replacing alfalfa silage with alfalfa pellets (28\% of diet DM) in diets fed to early lactation cows ( $<90 \mathrm{DIM})$ decreased DMI. When feeding poor-quality forages (Moore et al., 1964) or high-forage diets (Osuji et al., 1975), reducing forage particle size significantly increased DMI.

An interaction between RFC and forage particle size was observed for NDF, ADF, and starch intake. When cows were fed HMC, increasing forage particle size decreased $\mathrm{NDF}$ and $\mathrm{ADF}$ intake, whereas when cows were fed DC, increasing forage particle size increased NDF and ADF intake. Starch intake increased with increasing forage particle size when cows were fed HMC, but decreased with increasing forage particle size when cows were fed DC.

\section{Milk Production}

Cows fed HMC tended to produce more milk ( $P=$ 0.08 ) compared with cows fed DC (Table 4); however, this increase was observed only for the FS diets. In the literature, milk production responses to HMC are mixed. No significant difference in milk production was observed between cows fed HMC and DC in two studies (Chandler et al., 1975; Knowlton et al., 1998), whereas Clark et al. (1973) observed an increase in milk produc- tion when cows were fed HMC. A slight decrease in milk production was found by De Brabander et al. (1992) when HMC replaced a control concentrate.

Forage particle size did not affect milk yield, which is not surprising considering the lack of response in DMI when forage particle size was changed. Milk yield tended to increase with increasing forage particle size when cows were fed HMC and tended to decrease when cows were fed DC $(P=0.06)$. The tendency for an interaction of forage particle size and level of RFC might be explained by the changes in fiber and starch intake for HMC and DC diets when forage particle size was increased. A higher milk production for HMC diets with increasing forage particle size could be supported by the shift towards a lower fiber and a higher starch intake, whereas the opposite was true for the DC diets when forage particle size was increased (see Table 3 for nutrient intakes).

Solids-corrected milk yield was unaffected by diet, but tended to increase with increasing corn fermentability $(P=0.08)$. Because of lower DMI of diets containing HMC, efficiency of milk production, expressed as SCM production per unit of DMI, was higher for diets containing HMC than for diets containing DC. Greater ruminal fermentation is associated with higher energetic efficiency, which could explain the higher efficiency of milk production for the HMC diets compared to the DC diets.

Level of ruminally fermentable carbohydrate (RFC) did not affect milk fat content or yield. Oba and Allen (2000a) reported a depression in fat percentage when HMC replaced DC in high-starch diets (31\%), but no difference when diets contained $21 \%$ starch. Knowlton et al. (1998) found no difference in milk composition between DC and HMC when fed at $42.4 \%$ of diet DM. Despite the small particle size of the finely chopped silage, no effect of forage particle size was observed on milk fat percentage or fat yield. It was surprising that 
Table 4. Effects of level of ruminally fermentable carbohydrates and forage particle size on milk yield and milk composition.

\begin{tabular}{|c|c|c|c|c|c|c|c|c|}
\hline \multirow{2}{*}{$\begin{array}{l}\text { Dependent } \\
\text { production } \\
\text { variable }\end{array}$} & \multicolumn{4}{|c|}{ Treatments $^{1}$} & \multirow[b]{2}{*}{$\mathrm{SED}^{2}$} & \multicolumn{3}{|c|}{ Statistical significance ( $P$-value) } \\
\hline & HMCFS & HMCCS & DCFS & DCCS & & $\mathrm{RFC}^{3}$ & Forage & $\begin{array}{l}\text { RFC } \times \\
\text { Forage }\end{array}$ \\
\hline Milk, kg/d & 45.6 & 43.6 & 42.9 & 43.7 & 1.0 & 0.08 & 0.38 & 0.06 \\
\hline $\mathrm{SCM},{ }^{4} \mathrm{~kg} / \mathrm{d}$ & 41.0 & 41.1 & 39.6 & 40.0 & 1.1 & 0.08 & 0.61 & 0.98 \\
\hline $\mathrm{SCM} / \mathrm{DMI}$ & 1.76 & 1.68 & 1.59 & 1.59 & 0.05 & 0.003 & 0.27 & 0.31 \\
\hline Fat, \% & 3.42 & 3.60 & 3.48 & 3.62 & 0.16 & 0.72 & 0.19 & 0.86 \\
\hline Fat yield, kg/d & 1.55 & 1.59 & 1.49 & 1.57 & 0.07 & 0.44 & 0.26 & 0.65 \\
\hline Protein, \% & 3.05 & 3.12 & 3.15 & 3.10 & 0.05 & 0.23 & 0.60 & 0.09 \\
\hline Protein yield, kg/d & 1.38 & 1.37 & 1.35 & 1.33 & 0.04 & 0.15 & 0.51 & 0.95 \\
\hline Lactose, \% & 2.10 & 2.02 & 2.02 & 2.00 & 0.05 & 0.19 & 0.16 & 0.45 \\
\hline Lactose yield, kg/d & 0.96 & 0.88 & 0.89 & 0.89 & 0.04 & 0.16 & 0.21 & 0.17 \\
\hline $\mathrm{SNF}, \%$ & 8.4 & 8.6 & 8.7 & 8.5 & 0.08 & 0.20 & 0.63 & 0.03 \\
\hline SNF yield, kg/d & 3.84 & 3.76 & 3.71 & 3.70 & 0.09 & 0.13 & 0.47 & 0.61 \\
\hline
\end{tabular}

\footnotetext{
${ }^{1}$ Treatments: HMCFS = High-moisture corn and fine silage, HMCCS = high-moisture corn and coarse silage, DCFS = dry corn and fine silage, DCCS = dry corn and coarse silage.

${ }^{2} \mathrm{SED}=$ Standard error of difference.

${ }^{3} \mathrm{RFC}=$ Ruminally fermentable carbohydrate.

${ }^{4} \mathrm{SCM}=$ Solids-corrected milk, $\mathrm{SCM}=(12.3 \times$ fat yield, $\mathrm{kg} / \mathrm{d})+(6.56 \times$ solid nonfat yield, $\mathrm{kg} / \mathrm{d})-(0.075 \times$ milk yield, kg/d), (Tyrrell and Reid, 1965).
}

no reduction in milk fat percentage was observed when forage particle size was reduced to $3.7 \mathrm{~mm}$, considering the consistent response to reducing forage particle size found in other studies (Woodford et al., 1986; Woodford and Murphy, 1988) and the significant reduction in time spent chewing when forage particle size was reduced (Krause et al., 2002). Milk fat percentage is the animal response that often is associated with effective NDF (eNDF) content of a ration (Mertens, 1997). Based on the milk fat percentages observed in this study, and the lack of diet effect on milk fat percentage, it can be concluded that all four diets provided adequate amounts of eNDF to sustain milk fat percentage. However, diets containing FS did have numerically lower milk fat percentages than CS diets. The number of animals used in this trial might not have been adequate for detecting differences in milk components caused by dietary treatments.

Milk protein percentage and protein yield were similar across diets. For milk protein percentage, level of RFC and forage particle size tended $(P=0.09)$ to interact; protein percentage increased when forage particle size was increased in HMC diets, whereas it decreased in $\mathrm{DC}$ diets. This interaction might have been linked to the interaction between level of RFC and forage particle size on starch and fiber intakes. A higher starch intake for HMC diets when forage particle size increased could support an increase in microbial protein synthesis, which might result in a higher milk protein percentage. Lactose percentage and yield were not affected by diet. As for percent protein, percentage of SNF increased with increasing forage particle size for diets containing $\mathrm{HMC}$, but decreased with increasing forage particle size for diets containing DC. No effect of diet was found on yield of SNF.

\section{Rate of Passage of Liquids and Solids}

Increasing forage particle size increased liquid outflow rate from the rumen (Table 5), probably because of a higher saliva production for cows fed CS. Chewing activity, which is reported in a companion paper (Krause et al., 2002), was found to be higher for cows fed CS compared with FS; therefore, a higher saliva production would be expected for cows fed CS. Ruminal outflow rate of solids was not affected by level of RFC or forage particle size, but level of RFC tended $(P=0.06)$ to decrease ruminal retention. Transit time decreased when forage particle size was increased, and total mean retention time in the GI tract was decreased by increasing forage particle size and also decreased by increasing level of RFC. That mean retention time for solids was decreased with increasing forage particle size can seem surprising, but could be related to the fact that the marker used was ground wheat straw. The small particle size of the ground wheat straw might have allowed it to follow the liquid phase, which had an increased outflow rate when forage particle size was increased.

\section{Digestibilities}

Apparent total tract digestibility of $\mathrm{DM}$ and $\mathrm{OM}$ was higher for HMC than for DC diets, and so was total tract starch digestibility (Table 6). This finding is consistent with several studies (Knowlton et al., 1998; Ying et al., 1998), whereas Oba and Allen (2000b) found that only 
Table 5. Effects of level of ruminally fermentable carbohydrates and forage particle size on rate of passage of liquids and solids.

\begin{tabular}{|c|c|c|c|c|c|c|c|c|}
\hline \multirow[b]{2}{*}{$\begin{array}{l}\text { Dependent } \\
\text { variable }\end{array}$} & \multicolumn{4}{|c|}{ Treatments $^{1}$} & \multirow[b]{2}{*}{$\mathrm{SED}^{2}$} & \multicolumn{3}{|c|}{ Statistical significance ( $P$-value) } \\
\hline & HMCFS & HMCCS & DCFS & DCCS & & $\mathrm{RFC}^{3}$ & Forage & $\begin{array}{l}\mathrm{RFC} \times \\
\text { Forage }\end{array}$ \\
\hline Liquid outflow rate, $\% / \mathrm{h}$ & 12.2 & 13.3 & 11.4 & 14.2 & 1.2 & 0.96 & 0.03 & 0.35 \\
\hline Solid outflow rate & & & & & & & & \\
\hline $\mathrm{k}_{1}, \% / \mathrm{h}^{4}$ & 4.4 & 5.0 & 4.1 & 4.3 & 0.7 & 0.31 & 0.44 & 0.71 \\
\hline $\mathrm{k}_{2}, \% / \mathrm{h}^{5}$ & 16.3 & 16.3 & 13.8 & 21.0 & 4.9 & 0.76 & 0.32 & 0.32 \\
\hline Transit time, $\mathrm{h}$ & 12.8 & 11.6 & 13.2 & 9.3 & 1.2 & 0.32 & 0.01 & 0.13 \\
\hline Rumen retention time, $\mathrm{h}$ & 23.0 & 20.8 & 29.4 & 26.4 & 4.1 & 0.06 & 0.39 & 0.89 \\
\hline Mean retention time, $\mathrm{h}$ & 43.8 & 39.3 & 50.6 & 43.3 & 3.2 & 0.03 & 0.02 & 0.53 \\
\hline
\end{tabular}

${ }^{1}$ Treatments: HMCFS $=$ High-moisture corn and fine silage, HMCCS $=$ high-moisture corn and coarse silage, DCFS $=$ dry corn and fine silage, DCCS $=$ dry corn and coarse silage.

${ }^{2} \mathrm{SED}=$ Standard error of difference.

${ }^{3} \mathrm{RFC}=$ Ruminally fermentable carbohydrate.

${ }^{4} \mathrm{k}_{1}=$ Ruminal rate of passage.

${ }^{5} k_{2}=$ Lower digestive tract rate of passage.

ruminal starch digestibility increased, while total tract digestibility remained unchanged when HMC replaced DC. Total tract digestibilities of NDF and ADF were not affected by diet and were relatively high considering the type of diets fed. Knowlton et al. (1998) found that HMC tended to decrease total tract fiber digestibility compared with DC.

The ADF digestibility for HMC diets tended to decrease $(P=0.08)$ with increasing particle size when cows were fed HMC. This could be related to retention time, but the opposite occurred for the DC diets. Depressed fiber digestibility has been reported when forage particle size is reduced (Shaver et al., 1986; Woodford and Murphy, 1988). Ruminal $\mathrm{pH}$ was also measured in this study, and results are reported by Krause et al. (2002). The mean ruminal $\mathrm{pH}$ of 5.72 and 5.90 for HMCFS and DCFS, respectively, are both below the threshold where fiber digestion is inhibited in vitro (Hoover et al., 1984); therefore, it is surprising that fiber digestibility was unaffected by diet in this study.
In a review of the literature, Erdman (1988) found that 0.1 -unit decrease in mean ruminal $\mathrm{pH}$ in vivo resulted in a $3.6 \%$-unit decrease in ruminal ADF digestibility. In the current study, diets resulting in the lowest ruminal $\mathrm{pH}$ had the numerically highest fiber digestibility. Studies by Beauchemin et al. (2000) also found no relationship between ruminal $\mathrm{pH}$ and ruminal and total tract NDF digestibility. Starch digestibility tended ( $P$ $=0.06)$ to decrease when forage particle size was increased.

Kinetics of ruminal DM digestibility of the diets are shown in Table 7. The soluble DM fraction, a, was higher for HMC diets than for DC diets and higher for FS than for CS diets. The slowly digestible DM fraction, $\mathrm{b}$, was higher for DC than for HMC diets and increased with increasing forage particle size. The indigestible DM fraction, c, was lower for HMC than for DC diets. Lag time was similar across diets. Ruminal rate of digestion, $\mathrm{k}_{\mathrm{d}}$, was unaffected by level of RFC, but increased with increasing forage particle size. Effective

Table 6. Effects of level of ruminally fermentable carbohydrates and forage particle size on total tract digestibilities.

\begin{tabular}{|c|c|c|c|c|c|c|c|c|}
\hline \multirow[b]{2}{*}{ Digestibilities, \% } & \multicolumn{4}{|c|}{ Treatments $^{1}$} & \multirow[b]{2}{*}{$\mathrm{SED}^{2}$} & \multicolumn{3}{|c|}{ Statistical significance ( $P$-value) } \\
\hline & HMCFS & HMCCS & DCFS & DCCS & & $\mathrm{RFC}^{3}$ & Forage & $\begin{array}{l}\mathrm{RFC} \times \\
\text { Forage }\end{array}$ \\
\hline $\mathrm{DM}$ & 75.5 & 74.5 & 72.8 & 69.9 & 1.7 & 0.01 & 0.13 & 0.44 \\
\hline $\mathrm{OM}$ & 76.6 & 75.5 & 73.9 & 70.8 & 1.8 & 0.009 & 0.12 & 0.45 \\
\hline NDF & 54.3 & 47.6 & 46.2 & 47.7 & 3.6 & 0.13 & 0.33 & 0.12 \\
\hline $\mathrm{ADF}$ & 58.9 & 52.9 & 51.8 & 54.2 & 3.1 & 0.21 & 0.43 & 0.08 \\
\hline Starch & 97.7 & 97.1 & 94.5 & 91.6 & 1.2 & 0.001 & 0.06 & 0.19 \\
\hline
\end{tabular}

\footnotetext{
${ }^{1}$ Treatments: HMCFS = High-moisture corn and fine silage, HMCCS = high-moisture corn and coarse silage, DCFS = Dry corn and fine silage, DCCS = dry corn and coarse silage.

${ }^{2} \mathrm{SED}=$ Standard error of difference.

${ }^{3} \mathrm{RFC}=$ Ruminally fermentable carbohydrate.
} 
Table 7. Effects of level of ruminally fermentable carbohydrates and forage particle size on dry matter digetion kinetics.

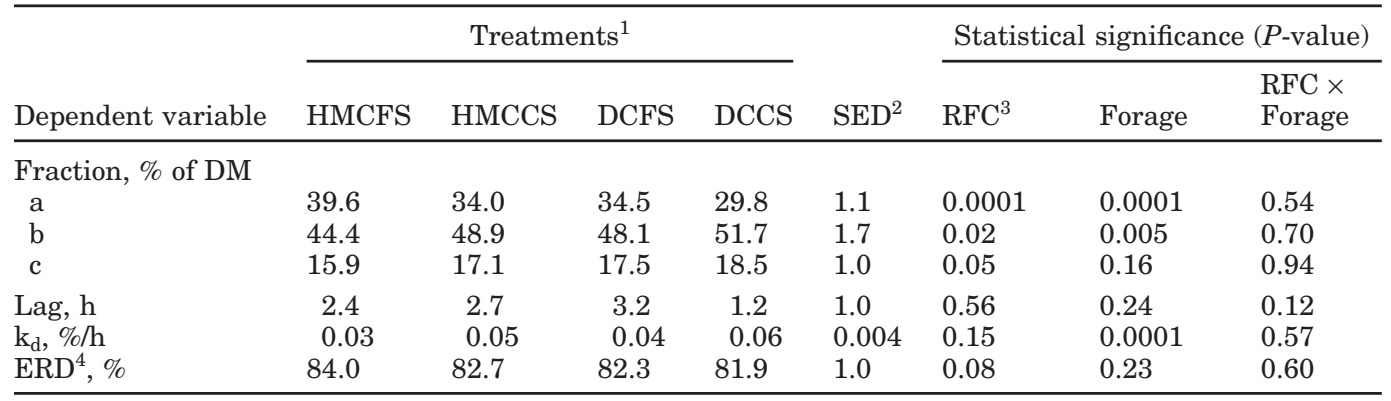

\footnotetext{
${ }^{1}$ Treatments: HMCFS = High-moisture corn and fine silage, HMCCS $=$ high-moisture corn and coarse silage, DCFS = Dry corn and fine silage, DCCS = dry corn and coarse silage.

${ }^{2} \mathrm{SED}=$ Standard error of difference.

${ }^{\mathrm{c}} \mathrm{RFC}=$ Ruminally fermentable carbohydrate.

${ }^{4}$ Effective rumen degradibility calculated using ruminal rate of passage of chromium mordanted straw $\left(\mathrm{k}_{1}\right): \mathrm{ERD}=\mathrm{a}+\left(\mathrm{b}\left(\mathrm{k}_{\mathrm{d}} /\left(\mathrm{k}_{\mathrm{d}}+\mathrm{k}_{1}\right)\right)\right)$.
}

ruminal digestibilty (ERD) of diet DM tended to be higher for HMC diets than for DC diets when calculated using the solid outflow rate found in the study. This was in agreement with the higher apparent total tract digestibility of DM observed for HMC diets compared with $\mathrm{DC}$ diets.

\section{Microbial Yield}

Urinary purine derivative excretion and microbial $\mathrm{N}$ production estimates are shown in Table 8. Daily excretion of the two purine derivatives, uric acid and allantoin, was not affected by level of RFC or forage particle size. However, total purine excretion increased when DC was replaced with HMC, as did absorption of microbial purines. Consequently, the calculated intestinal flow of microbial $\mathrm{N}$ increased by $49.7 \mathrm{~g} / \mathrm{d}$. Increasing the availability of ruminal fermentable energy in- creased ruminal microbial protein synthesis. The estimated increase in microbial $\mathrm{N}$ supply did not result in an increase in milk protein percentage or protein yield. However, microbial $\mathrm{N}$ supply increased numerically when forage particle size was increased in HMC diets and decreased numerically when forage particle size was increased in DC diets $(P=0.11)$. As mentioned earlier, cows fed HMC increased starch intake when forage particle size was increased, whereas cows fed DC decreased starch intake when forage particle size was increased. These numerical differences in microbial $\mathrm{N}$ supply supports the tendency for a forage particle size and corn-grain moisture interaction effect on milk protein percentage.

The results presented here differ from the results reported by Agca and Broderick (1995), who found an increase in milk protein yield when they increased grain fermentability by replacing high-moisture corn

Table 8. Effects of level of ruminally fermentable carbohydrates and forage particle size on purine derivative excretion. ${ }^{1}$

\begin{tabular}{|c|c|c|c|c|c|c|c|c|}
\hline \multirow[b]{2}{*}{$\begin{array}{l}\text { Dependent } \\
\text { variable }\end{array}$} & \multicolumn{4}{|c|}{ Treatments $^{1}$} & \multirow[b]{2}{*}{$\mathrm{SED}^{2}$} & \multicolumn{3}{|c|}{ Statistical significance ( $P$-value) } \\
\hline & HMCFS & HMCCS & DCFS & DCCS & & $\mathrm{RFC}^{3}$ & Forage & $\begin{array}{l}\mathrm{RFC} \times \\
\text { Forage }\end{array}$ \\
\hline Uric acid, $\mathrm{mmol} / \mathrm{d}$ & 41.0 & 79.9 & 41.6 & 41.0 & 23.3 & 0.31 & 0.26 & 0.26 \\
\hline Allantoin, $\mathrm{mmol} / \mathrm{d}$ & 418.2 & 394.8 & 387.0 & 375.2 & 39.1 & 0.74 & 0.37 & 0.53 \\
\hline Total, mmol/d & 457.8 & 486.3 & 426.0 & 403.4 & 23.1 & 0.003 & 0.86 & 0.12 \\
\hline Absorption, ${ }^{4} \mathrm{mmol} / \mathrm{d}$ & 484.1 & 518.4 & 446.7 & 419.3 & 27.4 & 0.002 & 0.86 & 0.11 \\
\hline
\end{tabular}

${ }^{1}$ Treatments: HMCFS = high-moisture corn and fine silage, HMCCS $=$ high-moisture corn and coarse silage, DCFS $=$ dry corn and fine silage, DCCS $=$ dry corn and coarse silage.

${ }^{2} \mathrm{SED}=$ standard error of difference.

${ }^{3} \mathrm{RFC}=$ ruminally fermentable carbohydrate.

${ }^{4}$ Calculations based on equation from Chen and Gomes (1992).

${ }^{5} \mathrm{DOMI}=$ digestible organic matter intake. 
with ground high-moisture corn. However, all four diets in our study were high in $\mathrm{CP}$, and protein was probably not limiting for milk production. Microbial yields in the present study were above the values reported by McCarthy et al. (1989), who used microbial purines in duodenal samples as a marker. The authors found microbial $\mathrm{N}$ yields of $286 \mathrm{~g} / \mathrm{d}$, in contrast to the $340 \mathrm{~g} /$ $\mathrm{d}$ found in this study, despite a similar intake of OM. Efficiency of microbial $\mathrm{N}$ production, expressed as grams of microbial $\mathrm{N}$ per kilogram of total tract digestible OM intake (DOMI) was not significantly affected by level of RFC, but tended to be higher for HMC than for DC $(P=0.10)$. This is likely related to a greater proportion of $\mathrm{OM}$ being digested in the rumen for HMC diets than for DC diets.

No effect of forage particle size on microbial $\mathrm{N}$ yield was found despite the lower ruminal $\mathrm{pH}$ for FS diets compared with CS diets (340.9 g N/d for CS vs. 338.4 g N/d for FS; see Krause et al., 2002 for ruminal pH results). A similar lack of relationship between ruminal $\mathrm{pH}$ and efficiency of microbial $\mathrm{N}$ production in vivo in both beef and dairy cattle was reported by Beauchemin et al. (2000). No depression in fiber utilization was found at the lower $\mathrm{pH}$ values in this study, which could explain the similar microbial N yield for FS and CS diets.

\section{CONCLUSIONS}

Dry matter intake was not affected by forage particle size, but increasing the level of ruminally fermentable carbohydrate in the diets by increasing corn moisture and changing processing decreased DMI. Decreasing forage particle size did not affect milk production, but increasing level of RFC tended to increase milk yield. This trend together with the lower DMI for cows fed high-moisture corn resulted in a higher efficiency of milk production for cows fed high-moisture corn compared with cows fed dry corn. No depression in milk fat occurred despite the small particle length of the forage, and both milk fat and protein percentage and yield were not affected by level of RFC or forage particle size. Feeding high-moisture corn increased total tract digestibility of DM, OM, and starch, compared with feeding dry corn, but fiber digestibility was unaffected by diet. Total purine excretion increased when level of RFC was increased and, consequently, the calculated intestinal flow of microbial $\mathrm{N}$ increased; however, this estimated increase did not result in an increase in milk protein percentage or yield. Forage particle size did not affect the estimated microbial protein yield.

Based on the results from this study, diets low in effective fiber and high in fermentable carbohydrates can be fed to midlactation cows without causing negative effects on diet digestibility and cow productivity.

\section{ACKNOWLEDGMENTS}

The authors thank Rhône-Poulenc Animal Nutrition for donating the Smartamine ML. Also, we thank Jerry Gunther, Robert Elderbrook, and the rest of the staff at the Dairy Cattle Research Center for taking care of and feeding the cows.

\section{REFERENCES}

Agca, C., and G. A. Broderick. 1995. Effect of grinding of high moisture corn on yield of lactating dairy cows fed alfalfa silage. J. Dairy Sci. 78(Suppl. 1):220. (Abstr.).

American National Standards Institute. 1988. Method of determining and expressing particle size of chopped forage materials by screening. ASAE S424, ASAE, St. Joseph, MI.

American National Standards Institute. 1995. Method of determining and expressing fineness of feed material by sieving. Page 461 in ASAE Standards 1995, ASAE, St. Joseph, MI.

Armentano, L., and Pereira, M. 1997. Measuring the effectiveness of fiber by animal response trials. J. Dairy Sci. 80:1416-1425.

Association of Official Analytical Chemists. 1990. Official Methods of Analysis. Vol. I. 15th ed. AOAC, Arlington, VA.

Bal, M. A., R. D. Shaver, A. G. Jirovec, K. J. Shinners, and J. G. Coors. 2000. Crop processing and chop length of corn silage: Effects on intake, digestion, and milk production by dairy cows. J. Dairy Sci. 83:1264-1273.

Beauchemin, K. A., L. M. Rode, and W. Z. Yang. 2000. Does low ruminal $\mathrm{pH}$ affect fiber digestion and efficiency of microbial synthesis in vivo? Reprod. Nutr. Dev. 40(Suppl. 2):206 (Abstr.).

Chandler, P. T., C. N. Miller, and E. Jahn. 1975. Feeding value and nutrient preservation of high moisture corn ensiled in conventional silos for lactating dairy cows. J. Dairy Sci. 58:682-688.

Chen, X. B., and M. J. Gomes. 1992. Estimation of microbial protein supply to sheep and cattle based on urinary excretion of purine derivatives-an overview of the tehcnical details. International Feed Resources Unit, Rowett Research Inst., Bucksburn, Aberdeen, AB2 9SB, UK. Occasional Publication.

Clark, J. H., R. A. Frobish, K. E. Harshbarger, and R. G. Derrig. 1973. Feeding value of dry corn, ensiled high moisture corn, and propionic acid treated high moisture corn fed with hay or haylage for lactating dairy cows. J. Dairy Sci. 56:1531-1539.

Combs, D. K., and L. D. Satter. 1992. Determination of markers in digesta and feces by direct-current plasma emission-spectroscopy. J. Dairy. Sci. 75:2176-2183.

CPM Dairy. 1997. Beta version 1.1. The Center for Animal Health and Productivity, School of Veterinary Medicine, Univ. of PA.

De Brabander, D. L., B. G. Cottyn, and C. V. Boucqué. 1992. Substitution of concentrates by ensiled high-moisture maize grain in dairy cattle diets. Anim. Feed Sci. Technol. 38:57-67.

Erdman, R. A. 1988. Dietary buffering requirements of the lactating dairy cow: A review. J. Dairy Sci. 71:3246-3266.

Goering, H. K., and P. J. Van Soest. 1970. Forage Fiber Analyses. (Apparatus, Reagents, Procedures, and Some Applications). Agric. Handbook No. 379. ARS-USDA, Washington, DC.

Grovum. W. L., and V. J. Williams. 1973. Rate of passage of digesta in sheep. 4. Passage of marker through alimentary tract and the biological relevance of rate-constants derived from the changes in concentration of marker in feces. Br. J. Nutr. 30:313-329.

Hartnell, G. F., and L. D. Satter. 1979. Determination of rumen fill, retention time, and ruminal turnover rates of ingesta at different stages of lactation in dairy cows. J. Anim. Sci. 48:381-392.

Hoover, W. H., C. R. Kincaid, G. A. Varga, W. V. Thayne, and L. L. Junkins. 1984. Effects of solids and liquid flows on fermentation in continuous cultures. 4. $\mathrm{pH}$ and dilution rate. J. Anim. Sci. 58:692-699. 
Knowlton, K. F., B. P. Glenn, and R. A. Erdman. 1998. Performance, ruminal fermentation, and site of starch digestion in early lactation cows fed corn grain harvested and processed differently. J. Dairy Sci. 81:1972-1984.

Krause, K. M., D. K. Combs, and K. A. Beauchemin. 2002. Effects of forage particle size and grain fermentability in midlactation cows. II. Ruminal $\mathrm{pH}$ and chewing activity. J. Dairy Sci. (submitted).

McCarthy, R. D., Jr., T. H. Klusmeyer, J. L. Vicini, and J. H. Clark. 1989. Effects of source of protein and carbohydrate on ruminal fermentation and passage of nutrients to the small intestine of lactating cows. J. Dairy Sci. 72:2002-2016.

McDonald, I. 1981. A revised model for the estimation of protein degradability in the rumen. J. Agric. Sci. 96:251-252.

Mertens, D. R. 1997. Creating a system for meeting the fiber requirements of dairy cows. J. Dairy Sci. 80:1463-1481.

Moore, L. A. 1964. Symposium on forage utilization: nutritive value of forage as affected by physical form. Part I. General principles involved with ruminants and effect of feeding pelleted or wafered forage to dairy cattle. J. Anim. Sci. 23:230-238.

National Research Council. 2001. Nutrient Requirements of Dairy Cattle. 7th rev. ed. Natl. Acad. Press, Washington, DC.

Nocek, J. E., and S. Tamminga. 1991. Site of digestion of starch in the gastrointestinal tract of dairy cows and its effect on milk yield and composition. J. Dairy Sci. 74:3598-3629.

Oba, M., and M. S. Allen. 2000a. Effects of conservation method of corn grain and dietary starch content on DMI and productivity of lactating dairy cows. J. Dairy Sci. 83(Suppl. 1):1043. (Abstr.).

Oba, M., and M. S. Allen. 2000b. Effects of conservation method of corn grain and dietary starch content on starch digestibility and efficiency of microbial $\mathrm{N}$ production in lactating dairy cows. J. Dairy Sci. 83(Suppl 1):1044 (Abstr.).

Osuji, P. O., J. G. Gordon, and A. J. F. Webster. 1975. Energy exchanges associated with eating and rumination in sheep given grass diets of different physical forms. Br. J. Nutr. 34:59-71.

Russell, J. B., J. D. O'Connor, D. G. Fox, P. J. Van Soest, and C. J. Sniffen. 1992. A net carbohydrate and protein system for evaluat- ing cattle diets: I. Ruminal fermentation. J. Anim. Sci. 70:3551-3561.

SAS User's Guide: Statistics, Version 7th. 1998. SAS Inst., Inc., Cary, NC.

Shaver, R. D., A. J. Nytes, L. D. Satter, and N. A. Jorgensen. 1986. Influence of amount of feed and forage physical form on digestion and passage of prebloom alfalfa hay in dairy cows. J. Dairy Sci. 69:1545-1559.

Shriver, B. J., W. H. Hoover, J. P. Sargent, R. J. Crawford, Jr., and W. V. Thayne. 1986. Fermentation of a high concentrate diet as affected by ruminal $\mathrm{pH}$ and digesta flow. J. Dairy Sci. 69:413-419.

Strobel, H. J., and J. B. Russell. 1986. Effect of $\mathrm{pH}$ and energy spilling on bacterial protein synthesis by carbohydrate-limited cultures of mixed rumen bacteria. J. Dairy Sci. 69:2941-2947.

Sudweeks, E. M., L. O. Ely, D. R. Mertens, and L. R. Sisk. 1981. Assessing minimum amounts and form of roughages in ruminant diets: Roughage value index system. J. Anim. Sci. 53:1406-1411.

Tyrrell, H. F., and J. T. Reid. 1965. Prediction of the energy value of cows milk. J. Dairy Sci. 48:1215-1223.

Udén, P., P. E. Colucci, and P. J. Van Soest. 1980. Investigation of chromium, cerium, and cobalt as digesta flow markers in rate of passage studies. J. Sci. Food Agric., 31:625-632.

Van Soest, P. J., J. B. Robertson, and B. A. Lewis. 1991. Methods for dietary fiber, neutral detergent fiber, and non-starch polysaccharides in relation to animal nutrition. J. Dairy Sci. 74:35833597.

Woodford, J. A., N. A. Jorgensen, and G. P. Barrington. 1986. Impact of dietary fiber and physical form on performance of lactating dairy cows. J. Dairy Sci. 69:1035-1047.

Woodford, S. T., and M. R. Murphy. 1988. Effect of forage physical form on chewing activity, dry matter intake, and rumen function of dairy cows in early lactation. J. Dairy Sci. 71:674-686.

Ying, Y., M. S. Allen, M. J. VandeHaar, and N. K. Ames. 1998. Effects of fineness of grinding and conservation method of corn grain on ruminal and whole tract digestibility and ruminal microbial protein production of Holstein cows in early lactation. J. Dairy Sci. 81(Suppl. 1):1330 (Abstr.). 